症例

粘膜下腫瘍様形態を呈し，確定診断までに 3 年間を要した 早期胃リンパ球浸潤性髄様癌の 1 例

川村病院, 東京慈患会医科大学病理学講座*
石
原

胃癌の進行過程で粘膜下腫瘍様形態をとり診断に苦慮する場合がある，確定診断まで に約 3 年を要し，その間の内視鏡像を追跡しえた 1 例を経験したので報告する，症例は 57歳，女性. 1996年11月，胃角小第の $\mathrm{m}$ 癌に対し EMR を行った.この時, 体中上部小

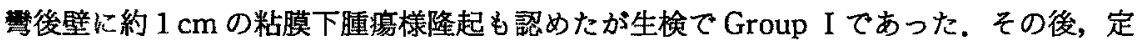
期的 follow up のため上部内視鏡を繰り返した. 1999年 7 月，病変は約 $1.5 \mathrm{~cm}$ に增大し， 生検で Group V（低分化型腺癌）であった，超音波内視鏡で樑達度 SM3 であり，腫瘍 の部位より, 胃全摘術 $(\mathrm{D} 1+\beta)$ を行った. 病理組織学的には低分化型腺癌で早期リンパ 球浸潤性髄様癌であった。術後経過は良好で術後37カ月の現在, 再発の兆候は認めてい ない.

索引用語：胃癌, 粘膜下腫瘍, リンパ球漫潤性髄様癌

\section{緒言}

リンパ球浸潤を伴う胃癌は粘膜下腫瘍様形態を呈 し, 術前診断が困難な場合がある。確定診断までに約 3 年間を要し，その間の内視鏡像の変化を追跡しえた 1 例を経験したので，文献的考察を加えて報告する. 症例

症例：57歳，女性。

主訴：上腹部不快感.

既往歴：特記すべきことなし.

家族歴：特記すべきことなし。

現病歴：1996年 9 月頃より上腹部不快感が出現し, 9 月24日受診，上部消化管内視鏡を施行した．胃角部 に早期胃癌を認め11月 2 日, EMR を施行した（図 1 )。 この時, 体上部小灣後壁に粘膜下腫晧様隆起も認めら れたが, 生検で Group I であった. その後, 隆起性病 変のフォローのため上部消化管内視鏡を定期的に行っ た (図 2).1996年10月の時点では約 $1 \mathrm{~cm}$ 弱の隆起を 認め，1997年まで大きさはさほど変わらず経過してお り，1998年 7 月の時点で直径 $1.5 \mathrm{~cm}$ ほどに増大し頂部

2002 年11月11日受付 2002 年12月13日採用

〈所属施設住所〉

=416-0907 富士市中島327
に浅い潰場を認めるようになった(図 $2 \mathrm{a} 〜 \mathrm{~d})$. ）しか し，1999年 4 月までに潰晹の中心部より生検を計 4 回 行ったがいずれも Group Iで(図 2 d，e），1999年 7 月に潰癔の中心部を生榆し Group V, 低分化型腺癌の 䛦断に至り（図 $2 \mathrm{f}$ )，8月25日入院した。

入院時現症：身長 $153 \mathrm{~cm}$, 体重 $60 \mathrm{~kg}$. 脈拍 $82 /$ 分, 血 圧120/76mmHg. 栄養状態良好で, 貿血, 黄晅なく表 在リンパ節も触知しなかった。また，心肺および腹部． に異常は認めなかった。

入院時一般検查所見 : 末血, 血液生化学検査および 検尿に異常はなかった。腫湟マーカーはCEA が0.2 $\mathrm{ng} / \mathrm{ml}$ と正常䉇用であった。

上部消化管造影所見（図 $3 \mathrm{a}$ ) : 何臥位二重造影て は, 体上部後壁に頂部に陥凹を伴う表面平滑な陰影欠 損を認めた。

内視鏡所見 (図 3 b)：体上部小警後壁に立ち上がり が比較的なだらかな隆起性病変を認めた，隆起部分の 站膜は周囲の正常粘膜と同様の性状で，頂部には白苔 を有する潰湟を認めた。

超音波内視鏡 (以下EUS) 所見 (図 $3 \mathbf{c}$ ) : 粘膜下層 に径 $17 \mathrm{~mm}$ 大の辺緑やや不整で内部エコー不均一な卯 円形低エコー域を認めた。

腹部 CT,エコーではリンバ節腫大や肝腫瘍を認め 


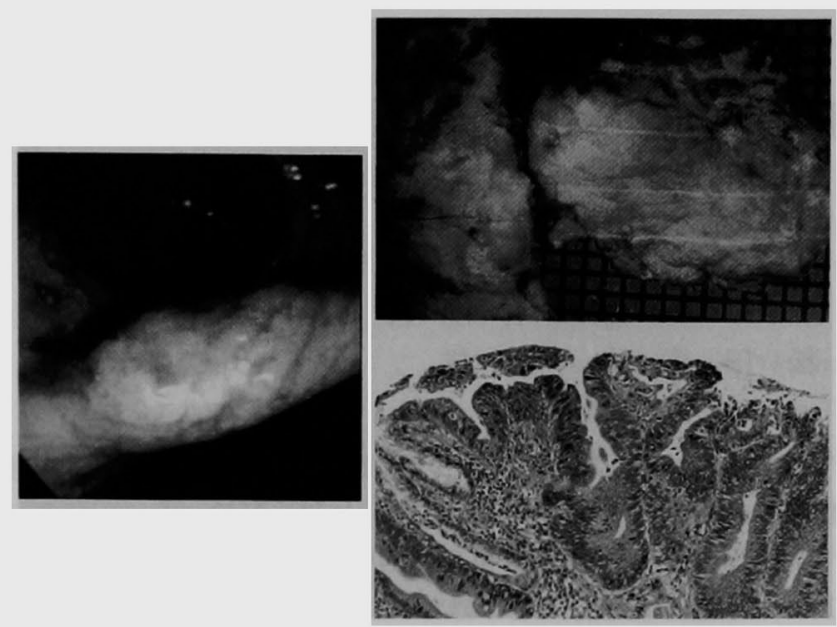

図 1 EMR を施行した胃角部早期癌

a 内視鏡像：胃角部に径 $15 \mathrm{~mm}$ 大の II a 病㚆を認める.

b 切除標本：右側標本にやや隆起した病変を認める.

c 組織像：粘膜層に高分化型腺癌が認められる.

$\mathrm{a} \mid \frac{\mathrm{b}}{\mathrm{c}}$
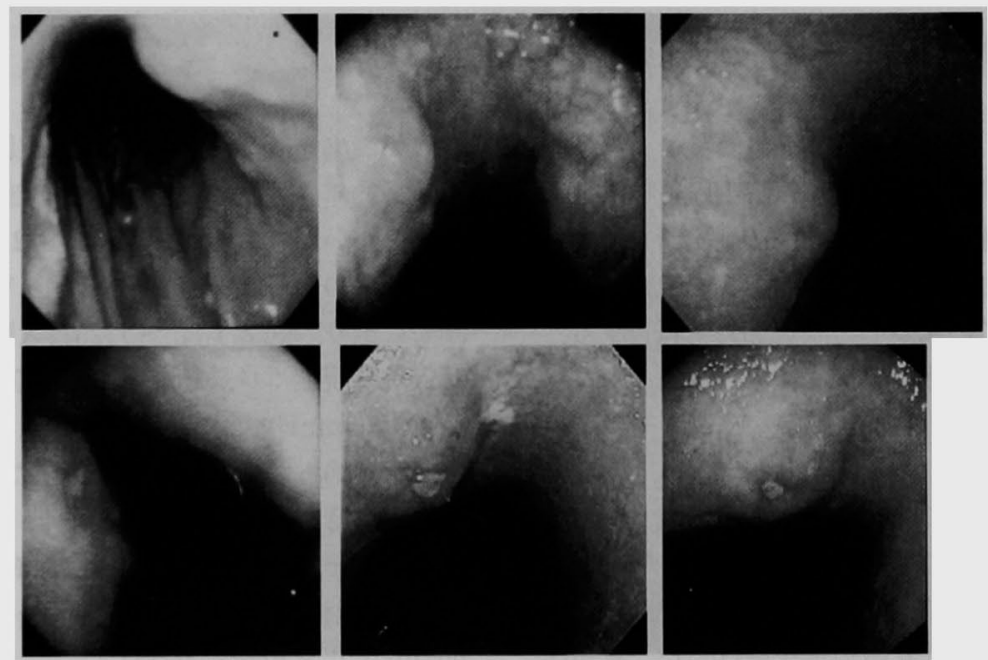

図 2 内視篭像の経時的变化：a ) 1996年10月．b）1996年11月．c）1997年 5 月.

d) 1998 年 7 月. e ) 1999年 4 月. f) 1999年11月.

なかった。

以上，画像所見と生検結果より体中上部の低分化型 腺癌の診断され，1999年 8 月31日，胃全摘 $(\mathrm{Dl}+\beta)$ を 施行した。

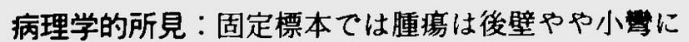
存在し，食道胃接合部からの距離は26mmであった。 隆起部分の最大径は $19 \mathrm{~mm}$ 大で, 中央から,やや肛門 側に陥凹を認めた。隆起部分はほほ正常粘膜で軽度の
びらんを伴った(図 4 a).ルーペ像では腫凚表面は正 常粘膜に覆われ，腫瘍は粘膜下層に增殖していた（図 4 b).組織学的には粘膜下層に低分化腺癌が随様に増 殖を示した $($ 図 $+c)$.

免疫組織学的：腫煬細胞は cytokeratin (CAM5.2) に特異的に染色された (図 5 a ). UCHL1 は腫瘍周囲 のリンパ球に強く染色され，浸潤するリンパ球は $\mathrm{T}$ cell と考えられた（图 5 b). 


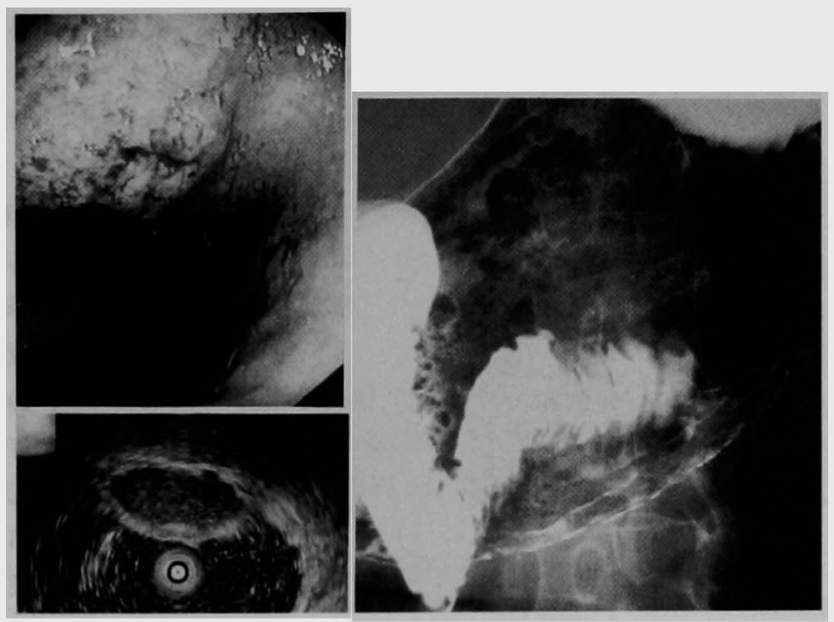

图 3 術前画像診断：a ) 上部消化管造影 (仰臥位二重造影像)。b) 内視篭像. c) EUS 像.

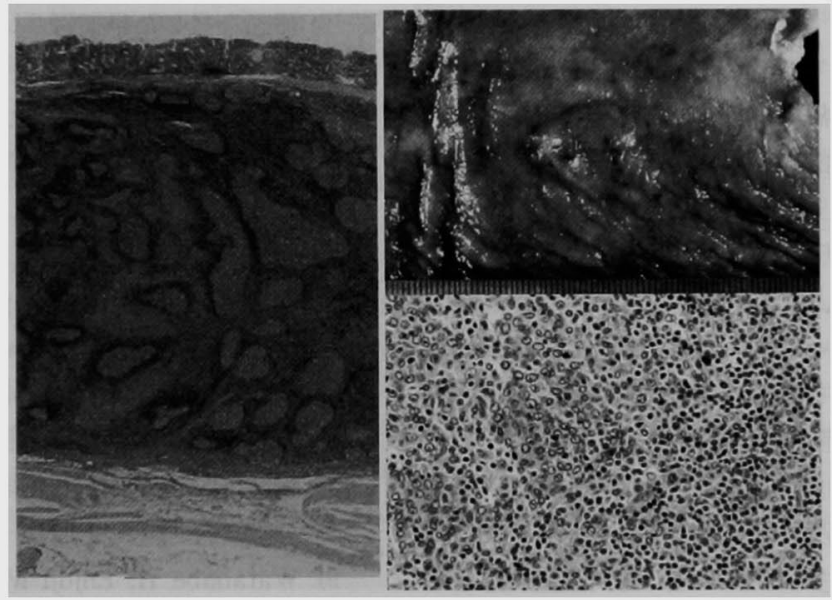

図 4 病理組織学的検查：a ) 固定標本. b) ルーペ像 (H.E.染色, $\times$ 4 ). c) 強搪大像 (H. E. 杂色, $\times 100$ )

$\mathrm{b} \mid \mathrm{a}$

以上より早期のリンパ球浸潤性髄様癌（medullary carcinoma with lymphoid stroma) と診断した. 総 合所見は $\mathrm{pT} 1, \mathrm{pN} 0, \mathrm{sH} 0, \mathrm{sP0}$ で fStage I A, 根治

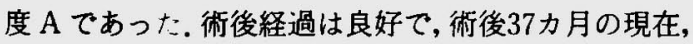
再発の兆候は認めていない.

\section{考察}

胃癌の進行過程において，病変の大部分が粘膜下発 育を示し，粘膜下腫崵様形態をとる場合があう．粘液 癌, 内分泌細胞癌, リンパ球浸潤性髄様癌などが含ま れるが", 粘膜下腫瘍との鑑別が重要である.内視鏡所
見における鑑別点として潰瘍形成, 粘膜面の微絊な変 化などが挙げられる゙が，その診断は必ずしも容易で なく長期間の観察を要した例も報告されている334). 本 例でも follow up 内視鏡を繰り返し、確定診断が得ら れるまで約 3 年間を要した。

一方, EUSは胃壁内における腫瘍の主座、形状，発 育様式, 大きさ，内部エコ一像の判断が可能であり, 診断上有用であったとの報告が増えている゙..本例で も，EUS を施行しており，粘膜下層に主座を置く腫瘍 と診断でき, gastrointestinal stromal tumor (GIST) 


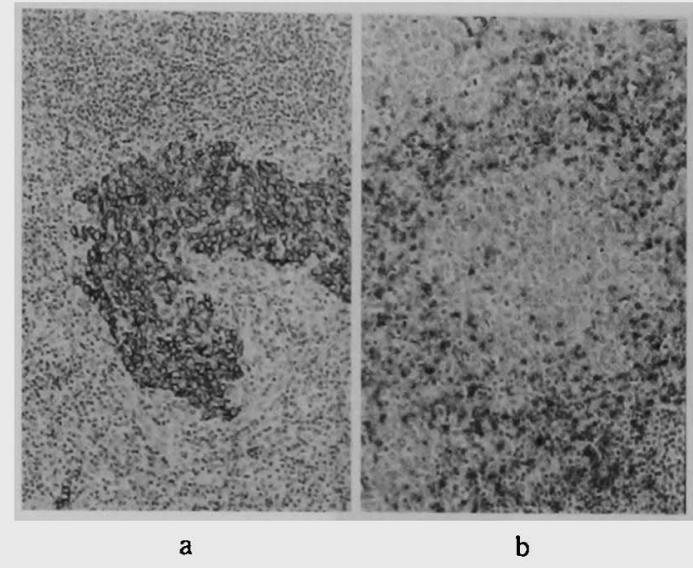

\section{図5 免疫粗織学的染色}

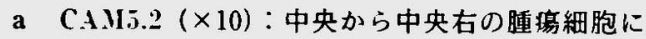
特異的にれ㢟された。

b [C CHL1 $(\times 10):$ 中央の腫韵細胞周囲のリンパ 球に強く染色された。

などの粘膜下腫瘍を除外できている。これにより，生 検を繰り返し，低分化腺癌し診断に至った。

自験例は, 病理組織学的にはリンパ球浸潤性檤様癌 であったが,著明なりンパ球浸潤を伴った胃癌は, 1921 年に NacCartyううにより，本邦では1968年に浜崎ら ${ }^{8)}$ により最初に報告された。本疾患は比較的稀で，その 頻度は胃癌全体の約 $1.1 \sim 4.0 \%^{91-12)}$ で, 早期癌に占め る割合は1.2〜5.8\%程度とされている. 好発部位は $\mathrm{M}$ 領域, C 領域が多く, 両者あわせて $63 \sim 86^{\circ}{ }^{\circ}$ 程度 ${ }^{10)-121}$ と推計される。肉眼形態は, 早期癌ではII a + IIc が多

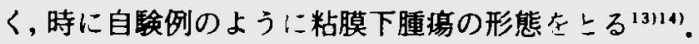
組織型は低分化型腺癌が多いな，一部に分化型腺癌を 伴うと言われる9．また，腫場周囲の浸膶リンパ球は T 細胞優位とされている。本例では解析しなかったが, EBER-ISH による腫場細胞のEB ウイルス陽性率は $90 \%$ 以上とされ EB ウイルア感染細胞の癌化が示唆さ れている ${ }^{15}$. 本腫瘍の予後は通常の癌に比へ良好とさ れる ${ }^{8 / 9111121}$.

従って、リンパ節郭清を伴う胃切除（病変部位によ り胃全摘）術にて治療は十分であると考えられるか， 早期癌でリンパ節転移を認める報告はなく，早期であ れば局所切除のみで根治できる可能性がある。

\section{結語}

胃早期リンパ球浸潤性の1例在経験した，腫喤は粘 膜下腫場様形態を示!，確定診断までに 3 年間を要し た。本症の補助診断に EUS が有用であった。
なお，本論文の要旨は静岡県外科医会第188回集談会 (富 士市）において発表した。

\section{文献}

1）河田佳代子, 石黑信吾, 辻 直子他：粘膜下腫湟 様形態を示す胃癌の臨床病理学的特徵. 胃と腸 $30: 739-746,1995$

2）福山隆之, 平岡哲朗, 蜂谷 勉他：粘膜腫痬様形 態を呈した胃癌一内視鏡的検討を中心に一．消化 器科 $8: 158-170,1988$

3）富永 潤，川瀨修二, 吉田昌弘他：粘膜下腫瘠様 形態を呈し 3 年 7 カ月間経過をみた早期胃癌の 1 例. 癌の臨 $38: 69-74,1992$

4）岡村正造，山本義樹，浅井俊夫他：約 3 年間も経 過を観察できた lymphoid stroma を伴う早期胃 癌の 1 例. Gastroenterol Endosc 25:1217122.2, 1983

5）斉藤忠範，桧山繁美，池田成之他：粘膜下腫瘍様 形態を呈した早期胃リンパ球漫潤性邻道様癌の 1 例。消内視鏡 $7: 899-9(1) 3 ， 1995$

6）源 利成，磨伊正義，太田孝仁他：胃リンパ球浸 潤性髄様癌の肉眼的特異性。胃と腸 $30: 799-$ 804, 1995

7) MacCarty WC, Mahle AE : Relation of differentiation and lymphocytic infiltration to postoperative longevity in gastric carcinoma. J Lab Clin Med 6 : 473-480, 1921

8）浜崎美景，沢山 興，栗矢 勉：胃の“リンパ球 浸潤を伴う解梾癌”一予後良好な胃癌の一組織型. 細胞核病理誌 $12: 115-1201,1968$

9) Watanabe $H$, Enjoji M. Imai $T$ : Gastric carcinoma with lymphoid stroma : Its morphologic characteristics and prognostic correlations. Cancer 38 : 232-243, 1976

10) Lertprasertuke $N$, Tsutsumi Y : Gastric carcinoma with lymphoid stroma : analysis using mucin histochemistry and immunohistochemistry. Virchows Arch A Pathol Anat 414:231241, 1989

11) Minamoto $T$, Mai $M$, Watanabe $K$, et al: Medullary carcinoma with lymphocytic infiltration of the stomach : clinicopathologic study of 27 cases and immunohistochemical analysis of the subpopulations of infiltrating lymphocytes in the tumor. Cancer 66:945- 
952,1990

12）岩下明德, 植山敏彦, 上田 豊: 胃のリンパ球浸

潤性鲔様癌 (medullary carcinoma with lymphoid stroma）の臨床病理学的検索. 胃上腸 $26: 1159-1166,1991$

13）黑沢正壱，石橋克之，飯塚美伸：粘膜下腫诸様形 態を示したいわゆるリンパ球浸潤性邻様癌の1例
-Epstein-Barr virus (EBV) 関連胃癌, Gastroenterol Endosc 41:2514-2519, 1999

14）田中祥介，上村志信，児玉 俊他：胃粘膜下腫瘍 様形態を呈した早期リンパ球浸潤性髄様癌の1

例. Gastroenterol Endosc 42:148-151, 2000

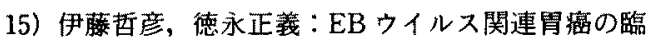
床病理。日臨 $55: 363-367,1997$

\title{
A CASE OF EARLY LYMPHOCYTIC INFILTRATING MEDURALLY CARCINOMA OF THE STOMACH WITH A MORPHOLOGY OF A SUBMUCOSAL TUMOR DEMANDED 3 YEARS FOR MAKING DEFINITE DIAGNOSIS
}

\author{
Yukio ISHIHARA, Masahiro IKEGAMI*, Tsuyoshi YOKOYAMA, \\ Hisao MATSUDA, Takeshi KAWAMURA and Toshio KAWAMURA \\ Kawamura Hospital \\ -Department of Patholugy. The Jikei University School of Medicine
}

Sometimes we have great difficulty in making diagnosis for gastric cancer appeared as a submucosal tumor in morphology in the course of its progress. We report such a case of medurally carcinoma of the stomach which demanded about 3 years until we made the definite diagnosis by following endoscopic pictures in a 57 -year-old woman.

The patient underwent EMR for $\mathrm{m}$ carcinoma of the lesser curvature at the angular notch in November 1996, when a submucosal tumor like elevation an about $1 \mathrm{~cm}$ in diameter was also found on the posterior wall of the upper middle portion of the gastric body adjacent to the lesser curvature. A biopsy of the elevation was reported to be Group I. Thereafter periodic follow-up studies with upper gastric endoscopy were conducted. In July 1999, the elevated lesion increased to about $1.5 \mathrm{~cm}$ in diameter and its biopsy disclosed Group $V$, poorly differentiated adenocarcinoma. Endoscopic ultrasonography revealed the tumor with the invasion depth of SM3. Considering the site of the tumor, a total gastrectomy $(\mathrm{D} 1+\beta)$ was performed. Histopathologically it was poorly differentiated adenocarcinoma and early stage of medurally carcinoma of the stomach with lymphoid stroma. The patient's postoperative course was uneventful. There have been no signs of recurrence, as of 37 months after the operation. 